University at Buffalo School of Law

Digital Commons @ University at Buffalo School of Law

Journal Articles

Faculty Scholarship

2-1-1982

\title{
Mirror, Mirror On The Wall: Histories of American Law Schools
}

Alfred S. Konefsky

University at Buffalo School of Law

John Henry Schlegel

University at Buffalo School of Law

Follow this and additional works at: https://digitalcommons.law.buffalo.edu/journal_articles

Part of the Legal Education Commons, and the Legal History Commons

\section{Recommended Citation}

Alfred S. Konefsky \& John H. Schlegel, Mirror, Mirror On The Wall: Histories of American Law Schools, 95 Harvard Law Review 833 (1982).

Available at: https://digitalcommons.law.buffalo.edu/journal_articles/719

\section{C. ${ }_{\text {COPYRIGHT }}^{\text {N }}$}

This Article is brought to you for free and open access by the Faculty Scholarship at Digital Commons @ University at Buffalo School of Law. It has been accepted for inclusion in Journal Articles by an authorized administrator of Digital Commons @ University at Buffalo School of Law. For more information, please contact lawscholar@buffalo.edu. 


\title{
COMMENT
}

\section{MIRROR, MIRROR ON THE WALL: HISTORIES OF AMERICAN LAW SCHOOLS}

\author{
Alfred S. Konefsky* and John Henry Schlegel ${ }^{* *}$
}

Numerous histories of law schools have been published in the last twenty-five years. In this Comment, Professors Konefsky and Schlegel review the field and discover a disturbing similarity. Rather than providing us with detailed knowledge of the unique characteristics of individual institutions and their inhabitants or the social context in which they are embedded, these histories reduce to carbon-copy tributes to the rise of the American law professor and the establishment of his preserve - the full-time, three-year, graduate program of pure law. The authors suggest the importance of, and provide some guidance for, serious scholarly inquiry in the area.

$\mathrm{T}$

HERE was a time when law schools were sold like indeed with - patent medicines and military schools, a time when Harvard advertised the size of its library and bragged that "two hundred courses in Harvard College alone" were "open to law students free of charge," when Cornell thought itself distinctive because it had "five full professors," and when Virginia emphasized that its "course designed for two years" was "sometimes completed in less." Times have changed. At least, none of these law schools would advertise, and for those schools that do, their advertisements focus only on the packaging rather than on any distinctive features of the product. They remind one of transcontinental airlines offering in-flight movies or of Avis trying harder. This decline of the free market in law schools has, at least in its broad contours, been thoroughly chronicled. ${ }^{2}$ But the details of what happened

* Associate Professor of Law, Faculty of Law and Jurisprudence, State University of New York, Buffalo.

** Professor of Law, Faculty of Law and Jurisprudence, State University of New York, Buffalo.

The authors wish to dedicate this piece to the memory of Art Leff, who understood about sugar and medicine. Thanks is due to Harry Arthurs, who helped us correct our understanding of the history of Canadian legal education, to Erika Chadbourn, who permitted us to quote from the papers of Thomas Reed Powell, and to Samuel F. Howard, Jr., who permitted us to quote from a letter written to one of us.

12 GREEN BAG law school advertisements ( 1890 ).

2 The standard chronicle is Stevens, Two Cheers for 1870: The American Law School, 5 PERSP. AMr. HIST. 405 (I97I). A more economic and less illuminating account is First, Competition in the Legal Education Industry (pt. I), 53 N.Y.U. L. REV. 3 II (I978). 
as law schools became homogeneous in program and differentiated largely by the social origins and employment destinations of their students are practically unknown to scholars. The recent publication of Tom Barnes' history of the Hastings Law School, ${ }^{3}$ coming as it does just shy of twenty-five years after the so-called "Goebel" history of the Columbia Law School, ${ }^{4}$ suggests that one might attempt to build a detailed understanding of the growth of American law schools by looking at the histories of law schools published in the last twentyfive years. And at first blush, the idea is reasonable. There are twenty partial or complete monographic studies, ${ }^{5}$ and they

${ }^{3}$ T. Barnes, Hastings College of the Law: The First Century (1978) [hereinafter cited as HASTINGs].

${ }^{4}$ Columbia Univ. Found. For Research in Legal History, A History of THE SCHOOL OF LAW, Columbia UNIVERSity (I955) [hereinafter cited as Columbia].

$s$ This essay reviews the following sources:

S. Epstein, Law at Berkeley: The History of Boalt Hall (1979) (unpublished doctoral thesis) [hereinafter cited as Berkeley].

T. Simon, Boston College Law School After Fifty Years (r980) [hereinafter cited as Boston CoLlege].

G. PEDERSEN, Buffalo Law School (I962) [hereinafter cited as Buffalo].

C. Cramer, The Law School at Case Western Reserve University (x977), reviezed in Johnson, Book Review, 22 AM. J. LEGAL HIST. 332 (I978).

Columbia, supra note 4, reviewed in Asper, Book Review, I6 MD. L. Rev. 358 (1956), and in Bathurst, Book Review, 6 INT'L \& CoMP. L.Q. I77 (1957), and in Bishop, Book Review, 49 LAw LibR. J. 300 (1956), and in Carr, Book Review, 73 LAW Q. Rev. 268 (I957), and in Hertz, Book Review, 37 CHI. B. Rec. 460 (I956), and in Morgan, Book Review, $5^{6}$ CoLum. L. REv. 957 ( 1956 ) (a brief sketch, but occasionally penetrating in details), and in St. John-Stevas, Book Review, 20 MoD. L. REv. 294 (1957), and in Yntema, Book Review, 6 AM. J. CoMP. L. 14I (I957).

A. Sutherland, The LaW at Harvard (I967) [hereinafter cited as Harvard], reviewed in Abel, Book Review, 18 U. ToRoNTo L.J. 213 (1968), and in Goodhart, Book Review, 80 HARv. L. REv. I8I8 ( 1967 ), and in Newmyer, Book Review, $54 \mathrm{~J}$. AM. HIST. 649, 650 ( $\mathrm{x}^{6} 67$ ) (notes lack of a sense of "inner struggles, personal battles, human tragedies, mistakes, and shortcomings"), and in Tucker, Book Review, 53 CORNELl L. REv. $35^{2}$ (1968), and in Twining, Book Review, 84 LAW Q. Rev. 40r, 404 (1968) (notes spare discussion of educational ideas in book), and in Wiecek, Book Review, 1969 WIS. L. REV. 1245, r252-53 (some suggestions for further research), and in Book Note, I3 AM. J. LEGAL HisT. 9I (I969); see also Leach, The Law at Harvard: A Quasi-Review with Personalia, HARV. L. SCH. BULl., Mar. 1968, at 4.

Hastings, supra note 3, reviewed in Ely, Book Review, 66 J. AM. HIST. 178 (I979), and in Johnson, Book Review, 84 AM. HIST. REV. 866 (I979).

Dedication and History, School of Law, Montana State University (I96I) [hereinafter cited as MONTANA].

J. RaHL \& K. Schwerin, Northwestern University School of Law - A SHORT HISTORY (rg60) [hereinafter cited as NORTHWESTERN].

P. Moore, A Century of LAW at Notre Dame ( 1969 ) [hereinafter cited as NOTRE DAME].

M. Kirkwood \& W. Owen, A Brief History of the Stanford Law School, I8931946 (Mar. I96I) (unpublished manuscript on file in Harvard Law School Library) [hereinafter cited as Stanford].

F. ELLSWORTH, LAW ON THE MIDWAY (I977) (University of Chicago), reviewed 
cover the terrain of legal education, lacking only an adequate representation of part-time schools. Yet after reviewing this scholarship, one is forced to conclude that twenty-five years have taught us little about the American law school. Why that is so, and what must be done if we are to learn more, are the subjects of this essay.

\section{I.}

To complain that institutional history is just that is to waste trees and ink. One need not love the genre to recognize its durability or to be less than surprised when the hero of the history of a law school turns out to be the institution itself. There are some exceptions: the history of the early years of the University of Oklahoma's law school, for example, is tucked into the biography of its first and long-time dean, and in William Johnson's history of legal education in Wisconsin before World War II, the University of Wisconsin's law school

in Paul, Book Review, 66 J. AMr. Hist. 425 (1979), and in Smith, Book Review, 22 AM. J. LEGAL HIST. 330 (I978).

E.G. BRown, LEgal Education at Michigan I859-1959 (1959), revieved in McWhinney, Book Review, 38 CAN. B. REv. 282, 284-85 (I960), and in Quarles, Book Review, 58 Mich. L. REv. 490 (1960), and in Shuman, Book Review, 6 WAYNE L. REV. 278 ( 1960$)$.

Stein, In Pursuit of Excellence (pts. I-3), 62 MiNN. L. REv. 485, 857, I I6 I (I978) [hereinafter cited as UNIVERSITy of MINNESOTA I]; $i d$. (pts. 4-6), 63 MINN. L. REV. 299, 809, IroI (1979) [hereinafter cited as UNIVERSITX of MinNEsota III]. All six parts are reprinted in R. STEIN, IN PURSUIT OF EXCELlence (I980).

W. FRATCHER, THE LAW BARN (I978) [hereinafter cited as UNIVERSITY of MisSOURI].

Coates, The Story of the Law School at the University of North Carolina, 47 N.C.L. REv. I (spec. issue Ig68).

D. McKnown, The DeAn (r973) [hereinafter cited as UnIversity of OKLAHOMA], reviewed in White, Book Review, I2 Hous. L. REv. 293 (1974), and in Wright, Book Review, 27 OKLA. L. Rev. 766 (1974).

D. Mays, The Pursuit of Excellence: A History of the University of RICHMOND LAW SCHOOL (I970) [hereinafter cited as UNIVERSITY OF RICHMOND].

J. Ritchie, The FIrst HUNDred Years (1978) [hereinafter cited as UnIVERSity OF VIRGINIA].

W.R. JOHNSON, SCHOOLED LAWYERS (1978) [hereinafter cited as UNIVERSITY of Wisconsin], reviewed in Calhoun, Book Review, 84 AMr. HIST. REv. 563 (I979) (good criticism), and in Dunn, Book Review, 103 LiBR. J. 89r (1978), and in Hobson, Book Review, 66 J. AM. HIST. 79 (I979).

One might also consult Bryson, The History of Legal Education in Virginia, I4 U. RICH. L. REV. 155 (I979) (materials on proprietary law schools); Dieffenbach, The Origin and Development of the Salmon P. Chase College of Law, I N. Ky. ST. L.F. I (1973); First, Legal Education and the Law School of the Past: A Single-Firm Study, 8 U. ToL. L. REV. I35 (I976); Jones, Texas Southern University School of LaveThe Beginning, 4 TEx. S.L. REv. 197 (1976-1977); Lawrence, The University of Oregon School of Law I884-1903: The Thornton Years, 59 OR. L. REv. 249 (1980); McKenzie, Farrah's Future: The First One Hundred Years of the University of Alabama Law School, 1872-1972, 25 ALA. L. REV. 121 (1972); Washington, History and Role of Black Law Schools, I8 How. L.J. 385 (1974). 
is not the hero but the goat. But exceptions aside, most of these histories are not primarily stories of personal or even group achievement but rather almost imperceptible variations on a now well-known theme. Simply put, the school grows from humble, but auspicious, beginnings to early triumphs and then through occasional hard times, though with never more than a momentary temptation to backslide from fixed and noble goals, to a place - if only a small place - in the sun. Perhaps one should expect little else from an art form by and large designed to separate alumni from their money. Every institution needs a noble past, if only as a base upon which to build an assertedly better future. But it is hard to believe that most law schools in fact had a history as archetypically heroic (that is, unilluminating) as one would think from reading these examples. Indeed, the sameness of the story, especially the sense that, inevitably, each school should become a little Harvard (even Harvard!) is overwhelming.

This feeling of inevitability, akin to reading a whodunit novel for the second time, is the most extraordinary aspect of all of these books. One sees it even in Arthur Sutherland's Harvard history, where the pre-Langdell era of Theophilus Parsons and Emory Washburn is presented as quite obviously not up to the Harvard ideal, even though its standard of scholarship, if not its level of excitement, was surely as high as in many years since. ${ }^{6}$ Similarly, this sense of destiny subtly dominates the Columbia history, in which it is soon apparent that Stephen Nash and Seth Low are the forces of progress and light, while lovable old Theodore Dwight, patiently leading his students through the corpus of the law, is only the midwife for glories yet to come. ${ }^{7}$ Perhaps obvious winners can be expected to see the past that way. Harvard and Columbia, early exponents and exporters of case law, Socrates, and the Langdellian way, may take understandable, if smug, satisfaction in their own vitality and that of the system they fostered. But what of Hastings, a night school until after World War II and the once proud possessor of an attractive alternative to the Langdellian tradition in the teaching and scholarship of John Norton Pomeroy? From the first page of the discussion of the career of Pomeroy's successor and devoted follower, William R. Slack, it is clear that Pomeroy's enterprise is doomed. ${ }^{8}$ Similarly, Virginia, where case method instruction was not introduced until one of its faculty took an S.J.D. at

${ }^{6}$ See HaRVARD, supra note 5, at I40-6r.

${ }^{7}$ See Columbia, supra note 4 , at Io8-17.

${ }^{8}$ See HASTINGS, supra note 3, at I16-I9, I24-29. 
Harvard in the r930's, ${ }^{9}$ seems only to be marking time for the sixty years after the Civil War. Even more telling is Johnson's Wisconsin. Johnson, who plainly thinks that modern - that is to say, post-Langdell - legal education is a disaster, draws an attractive, if overly romantic, picture of pre-modern legal education as a union of practice - apprenticeship - and theory - university training. ${ }^{10}$ Yet he can do little more than lament the inevitable. He presents his model, the Marquette Law School, as a small, poor victim of "heavy" politics, a helpless sapling in the path of a bulldozer. ${ }^{11}$ Indeed, in virtually every book, once Langdellian orthodoxy - the threeyear graduate program of "pure law" taught from cases by the Socratic method - is established, the force of the narrative is spent and each author must grope for a new theme. Usually he or she settles for chronicling the orderly succession of deans and the occasional struggle to acquire new quarters.

Now only in the silliest deterministic sense was the Langdellian revolution ever inevitable. In I89o over fifty university-affiliated law schools, with over four thousand students, supplied perhaps a quarter to a third of the new lawyers entering practice. ${ }^{12}$ Only three of these schools - Harvard, Columbia, and Iowa - hospitably entertained the Langdellian views. ${ }^{13}$ The rest used some mixture of text, lecture, recitation, case analysis, and what-have-you. In those days, at least, it was not obvious that Langdell's law school would sweep the country. True, the bearded genius of Austin Hall had several things going for him. His program was one that made entry into the profession difficult for the poor and thus had much appeal in elite professional circles. ${ }^{14}$ And as a result of Ames' efforts, Langdell had an impressive collection of young missionaries out peddling his system and with it their own professional identity. ${ }^{15}$ But the ultimate triumph of that system, even in the narrow world of the university-affiliated day law school, was not apparent until at least Igro when the West Publishing Company thought that the market was large enough to support an entire series of case books. ${ }^{16}$ Even then,

\footnotetext{
9 UNIVERSITY OF VIRGINIA, supra note 5 , at $73-74$.

${ }^{10}$ See UNIVERSITX OF WISCONSIN, supra note 5 , at 42-55.

${ }^{11} I d$. at $133-48,155-64$.

12 See A. Reed, Training for the Public Profession of the LaW 442 (I92 I).

13 I REPORT OF THE COMMISSIONER OF EDUCATION FOR THE YEAR I890-9x, at 4I4-32 (I894) (detailed review of curriculum at law schools).

${ }^{14}$ See J. Auerbach, Unequal Justice (1976).

is See J. Schlegel, Between the Harvard Founders and the American Legal Realists: The Professionalization of the American Law Professor (Oct. 27, 1979) (paper presented at the gth Annual Meeting of the American Society for Legal History, Williamsburg, Va.).

${ }^{16}$ See The American Casebook Series, 2 AM. L. Sch. REV. 276 (1909).
} 
West hedged its bets by starting a second series of texts with accompanying casebooks for those schools, obviously still numerous, in which both text and cases had their place in the classroom. ${ }^{17}$ And in I9Io there was an entirely new market, the part-time night law school, that ten years later was blessed by the American Bar Association. ${ }^{18}$ Apparently, these schools were hardly touched by case method instruction, though we know little more than that about most of them. ${ }^{19}$

The view that the Langdellian revolution was inevitable undercuts what should be a main focus of institutional history: the uniqueness of the development of an institution. Thus, the sameness of these accounts appears in fact to be altogether ahistorical; the drama of birth and success is played almost without regard to the life within the institutions. If these histories are to be believed, contemporary law schools are unique among institutions only in that they are completely without traditions, save that of pursuing and occasionally finding excellence. To the extent that students who do not become faculty live at all, they seem to do so only on the law review and the moot court board, though they are sometimes reincarnated as alumni. The faculty themselves are treated as faceless teaching clones who produce uniformly interesting, high quality scholarship in total isolation from each other and who collaborate only occasionally to raise academic standards or reorganize the curriculum. The one grand exertion for which a school will surely unite is to acquire a new building. Even here, however, the school acts as every other school acts, and the voices of individuals are drowned out by the chant of the mass that it must have more room.

Yet every law school must have some traditions. They may only be poor teaching and hard grading rather than such quaint customs as dressing all third year students in bowlers and canes for "Derby day" at Montana in the teens, ${ }^{20}$ or the weekly faculty luncheon meeting at Yale in the twenties and thirties, or Friday afternoon "wine mess" at Chicago in the sixties, but they are there. Eighty to ninety percent of the students in a law school never play the law review-moot court game, and it is this large group that sets the dominant culture of a school. Richmond in the twenties, for example, was a

17 See, e.g., 3 AM. L. SCH. REV. back cover (Spring I913) (advertisement).

${ }^{18}$ Stevens, supra note 2, at $460-6 \mathrm{I}$.

19 Stevens, Law Schools and Legal Education, 1879-1979: Lectures in Honor of roo Years of the Valparaiso Law School, I4 VAL. U.L. REV. I79 (I980), makes the first attempt to learn something about these schools.

${ }^{20}$ Montana, supra note 5, at 32-33. 
night school, and students prepared for class strap-hanging on the trolley line from downtown to the suburban campus. ${ }^{21}$ At Oklahoma, ${ }^{22}$ they engaged in rather elaborate high jinx "wars" with other groups of undergraduates. And at several places at different times, more bridge seems to have been played than law studied. ${ }^{23}$

While one can perhaps understand faculty authors slighting what is basically student culture, one has a harder time understanding faculty distortion of faculty culture. The notion that a move to better quarters has such an impact on a law school that a detailed recounting of the trials and tribulations of the acquisition is appropriate is thoroughly belied by these volumes. In not one instance is it shown, or even implied, that scholarship or teaching improved as a result of a move to more spacious quarters. In fact, one occasionally notices that the move broke a tight-knit fellowship that grew up in the earlier, more cramped world. ${ }^{24}$ But such acknowledgements that there are even elements of a faculty culture are few. For example, there are but four instances in all these stories in which faculty can be seen actually arguing with each other, ${ }^{25}$ though some intramural feuds between faculty are famous, such as the one that pitted Pound against Frankfurter and Landis. ${ }^{26}$

The unilluminating sameness of these accounts is continued into the one facet of law school life that one learns most about - the almost lockstep procession of deans. It is as if these books follow a rule drawn from boys and baseball cards - one dean is worth six faculty. If faculty get three lines apiece, deans get a page or two; if faculty get a paragraph or two, deans get pages or on occasion even a chapter. Now all this would be fine if the question of who was dean of a law school was shown to matter somehow. But strange as it may seem when virtually every volume marks the beginnings and endings of eras with changes in the deanship, there is almost no evidence that who the dean was made any difference. A larger collection of noisy barrels it would be hard to find. Few after Langdell seem to have had any coherent, much less original, thoughts on legal education and those who did, for

21 UNIVERSITY OF RICHMIOND, supra note 5, at 29-30.

22 UNIVERSITY OF OKLAHOMIA, supra note 5 , at 223-26.

${ }^{23}$ See, e.g., D. RITCHIE, JAMES M. LANDIS: DEAN OF THE REguLATORS 17 (1980).

${ }^{24}$ UNIVERSITY of Missourd, supra note 5, at 34-43.

${ }^{25}$ Columida, supra note 4, at 299-305; UNIVERSiTy of MissourI, supra note 5 , at 85-90 (two instances); Berkeley, supra note 5 , at 384-85.

${ }^{26} \mathrm{D}$. RITCHIE, supra note 23 , at $35,37,40-42,50$. 
example, Harlan F. Stone ${ }^{27}$ had little impact beyond their office door. Yet the implied proposition that deans do not matter is clearly counterintuitive. Many deans have at least had the power to hire and fire juniors and to make teaching assignments. ${ }^{28}$ But though there are exceptions - Wigmore is one ${ }^{29}$ and Vance in faculty recruitment at Minnesota another $^{30}$ - the average dean in these histories appears to do little more than hitch his charges to the dog sled and mush "Excellence!"

And if these histories reveal only darkly the life within law schools, the life outside them is not seen at all. Each school floats through time anchored only to its beginning - the day they opened the doors - and to an assumed present. Except for Boston College ${ }^{31}$ and Buffalo, ${ }^{32}$ each leads a kind of Stover at Yale existence in between, a life of perpetual spring green and ivy-covered tudor limestone, with only the mistiest of attachments to a world outside its doors. Interruptions there are - two world wars and, in the most recent books, Cambodia - but clearly they are only interruptions, for order returns soon after the late unpleasantness. A particularly glaring example of this social isolation is in the treatment of women. Every author of a book written since r975 remarks on the phenomenal influx of women into law schools in the past decade. Occasionally an author will even somewhat selfconsciously point out the first female graduate and recount her truncated career. But not one book seriously discusses the exclusionary practices by law schools in the years before I 968 or the chance conjunction of two events: a decline in law school applications as Lyndon Johnson began to draft law students and the first stirrings of a vocal, revitalized women's movement, a coincidence that makes law schools look sub-

\footnotetext{
27 Columbia, supra note 4 , at 226-30.

${ }^{28}$ See, e.g., Gilmore, The Good Faith Purchase Idea and the Uniform Commercial Code: Confession of a Repentant Draftsman, 15 GA. L. REv. 605, 605 (198I) ("At the end of World War II, I gratefully accepted an invitation to join the faculty of the Yale Law School. When I reported for duty in New Haven, Dean Wesley Sturges said to me, 'You will teach sales.' I said, 'Yes, sir.'")

29 NORTHWESTERN, supra note 5, at 19-2I. The extent of Wigmore's influence on that school is however better captured in W. ROALFE, JOHN HENRY WigMORE: SCHOLAR AND REFORMER (1977).

${ }^{30}$ UNIVERSITY OF MINNESOTA I, supra note 5 , at 867-72.

${ }^{31}$ Boston College, supra note 5 , at $6,15,21$ (reveling in its early downtown Boston existence).

32 Buffalo, supra note 5 , at $3 \mathrm{x}, 37,47,59$ (knowing only a downtown existence at the time its history was written).
} 
stantially more opportunistic than one might otherwise be led to believe. And for all the furor over DeFunis, ${ }^{33}$ the problems of blacks and of fashioning affirmative action programs get little if any attention, though here Bob Stein is a clear and important exception. ${ }^{34}$

Other social, political, and intellectual events are similarly conspicuous only by their absence. Labor unrest in the nineties is touched nowhere; progressivism apparently reached only Berkeley, ${ }^{35}$ Wisconsin, ${ }^{36}$ and perhaps Harvard; ${ }^{37}$ legal realism infected only Columbia and did little more there than immunize the patient; ${ }^{38}$ the New Deal touched Columbia, ${ }^{39}$ Harvard, ${ }^{40}$ and Berkeley lightly ${ }^{41}$ by drawing teachers away from class; and the McCarthy era reached only Berkeley ${ }^{42}$ and, in a veiled way, Notre Dame. ${ }^{43}$ Perhaps these omissions are merely an accurate reflection of the oft-decried insularity of law schools. But the picture thus painted may be even more revealing. In omitting any mention of the outer world impinging on their private island, law school historians are simply replicating what goes on in most law schools - the treating of law as an autonomous and apolitical ordering. Intellectual movements, large-scale political events, debates on social issues, theoretical musings, and ideology warrant no mention in a law school history for they apparently have no significant influence on the teaching of law at most schools. To the extent that they are discussed at all in the law school classroom, they are kept within a framework that prevents fundamental analysis and criticism. By ignoring all but the pursuit of the narrowest conception of law, law school historians reveal their own ideology. They do not have to scream from the rooftops, "Social context is irrelevant." All they need do is sing BoolaBoola and exit stage left.

${ }^{33}$ DeFunis v. Odegaard, 4 I6 U.S. 3 I2 (I974) (suit challenging law school's affirmative action program declared moot).

${ }^{34}$ See UNIVERSITY OF MINNESOTA I, supra note 5, at 870-79, I209-I3.

${ }^{35}$ Berkeley, supra note 5, at $73-80$.

${ }^{36}$ UNIVERSITY OF WISCONSIN, supra note 5, at I64-70.

${ }^{37}$ One has to look carefully to discern Pound's ties to progressive causes; Frankfurter's are a trifle clearer. HARVARD, supra note 5, at 237-39, $24 \mathrm{r}-42$.

${ }^{38}$ Columbia, supra note 4 , at $297-99$ (seen as a movement in legal education only).

${ }^{39} \mathrm{Id}$. at $336-37$.

40 HARVARD, supra note 5 , at $287-88,302-03$.

41 Berkeley, supra note 5, at 226-28.

42 Id. at 303-04.

43 Notre DaMe, supra note 5 , at 86-87. 
II.

Why these histories are collectively so uninformative, why we have learned so little in twenty-five years is a question with many answers. One explanation is intimately related to the genre itself and bears only brief mention. Given that these are institutional histories whose supposed audience is alumni, it is not surprising that the institution receives a certain amount of protection. Muckraking and serious inquiry into reasons for failure would not be the appropriate vehicle with which to launch fund-raising efforts. You protect what you hope to build. Thus, one senses in the texts the notion that this is not really a serious form of scholarship, an impression that is reinforced by the fact that most of the authors are aging or retired faculty members, devoted alumni, or, curiously, soonto-be deans.

A second explanation is directly related to the first. That most American legal history is tory history is now a commonplace perception, ${ }^{44}$ and protectiveness towards institutions is an old tory trait. Examples of the political conservatism in all of this work are legion. For instance, at Boston College in I970, Father Drinan resigned as dean to run for Congress, where he could press his antiwar concerns more effectively. Soon thereafter, the United States invaded Cambodia, students were shot and killed at Kent State and Jackson State, and campus after campus, including Boston College, was closed by antiwar protests. Of these events, the school's historian recounts, "In retrospect, it is clear that most students joined on for the free ride," and then observes, "Only a day or two of classes were missed in any subjects ...."45 Some damage was done, but not much. "[E]xaminations, however, were devastated":46 that is, "[t]he faculty reluctantly agreed to allow second and third year students to pass courses on certification that they had completed class work," 47 which is to say a handful of people passed a course they would not otherwise have passed and everyone managed to escape for one semester from the school's grading system. But all was not lost. "First year tests proceeded normally." 48 The press of meritocratic professionalism here is astonishing.

Other examples might be offered, indeed other examples

${ }^{44}$ Horwitz, The Conservative Tradition in the Writing of American Legal History, I7 AM. J. LEGAL HIST. 275 (I973), offers the first significant statement of this position.

45 Boston COLlege, supra note 5 , at 49.

${ }^{46} I d$.

47 Id.

${ }^{48} I d$. 
related to the Cambodian invasion, ${ }^{49}$ but the key point is to underline the traits of tory legal history that all of these books share. One is the deep concern with continuity. Another is the obsessive interest in origins, especially when origins are unremarkable. And for tories the unwillingness to discuss unpleasant, even discriminatory, aspects of legal education like the exclusion of women and blacks, or the attempt to exclude immigrants - is, if not forgivable, at least understandable. It is winners' history of the most conventional variety written from the top down.

It would be tempting to pass off the other defects in these works - the invisible faculty and students, the visibly unimportant deans, the passion for new buildings, and the sameness of the story of rising standards - to toryism and be done with it. Tory history, however, is usually heavy with the cultivation of and respect for tradition. Yet, as we have noted, one of the characteristics of these works is the pronounced absence of tradition. A more important explanatory variable than pure toryism is the commitment to a world view that is so distinctively a part of these histories of law schools that it is slighted if lumped together with other conservative ways of thinking. It is the world view of the university legal academic - case method, law review scholarship, and the progress of rising standards. It is, in a word, the world view of the academic lawyer as a "professional."

The concern of legal academics over their professional role dates back at least as far as Christopher Columbus (Langdell, that is), who when announcing that the law was a "science" opined that, if on the contrary it was but a "species of handicraft," "a university will best consult its own dignity in declining to teach it." 50 The linchpin of that identity was the case-method/common-law/private-law system that Langdell set into concrete at Harvard. ${ }^{51}$ This system allowed the legal academic exclusive control over a corner of the university community and thus the chance to profit from that control. ${ }^{52}$ Part of that profit hinged on the ability to exclude others from teaching law through the attempt to establish the full-time, day, university-affiliated law school as the only route to the practice of law. Similarly, part of the way to attain respectability in the university community, as well as to stay relatively

\footnotetext{
49 See, e.g., UNIVERSITY OF MIssourI, supra note 5, at 88-90.

so Address by Dean Langdell, Harvard University 'Quarter-Millenial' Celebration (Nov. 5, I887), reprinted in 3 LAW Q. REv. 123, I24 (1887).

${ }^{51}$ See HARVARD, supra note 5 , at 162-205.

52 Here we adopt a parallel of the argument advanced in M. LARSON, THE RISE of ProfessionalisM at xvi-xvii (1977).
} 
free from university administrative control, was to establish law, like medicine, as a wholly graduate degree program. Thus, in the case method is found both the distinctiveness of and protective coloration for the modern American law teacher. It informs his identity as a teacher and scholar whose method is unique, and at the same time allows him to be just one of the boys at the faculty club.

The development and success of this identity was inevitable only on the assumption that Langdell's system was somehow intellectually necessary for the development of the legal profession. But that assumption has consequences that expose members of the legal profession as grasping monopoly capitalists - a view that surely few, if any, of these authors would be eager to embrace. Three years of daytime, pure-law, graduate education are by no means necessary to become an accomplished legal technician. But if it is assumed that they are necessary to join the intellectual elite of the profession, then those who cannot afford that education will be effectively barred from the ranks of the elite. Jerold Auerbach ${ }^{53}$ and Robert Stevens ${ }^{54}$ have argued persuasively that one of the reasons for the movement for higher admissions standards for law school and for the bar between 1890 and 1940 was American nativism, a wish to keep the poor in general and the immigrant poor in particular out of the legal profession. ${ }^{55}$ These efforts were made simply by requiring a minimum number of class hours for accreditation. The number of costly years of education required was thereby increased, and many part-time schools, which were less costly because they permitted students to support themselves while attending school, were closed. The case method fits neatly into this pattern by giving teachers something to teach and students something to puzzle over during the three years of full-time study.

Once this complex of elements that makes up the professional identity of the law professor is isolated, much that is puzzling about the boring sameness of these accounts becomes explicable. Each of these law school histories is indirectly a paean to the professional law teacher. Each chronicles his rise and the foundation of his distinctive identity at a given school. Thus, in each of them the major theme is the slow progression of advancing standards, and the high point is the establishment of case method orthodoxy. The contingency of both these

${ }^{53} \mathrm{~J}$. AUERBACH, supra note $\mathrm{I}_{4}$.

54 Stevens, supra note 2.

55 The failure of any of these law school histories even to mention Auerbach's and Stevens' scholarship is but another example of their failure to take account of any social context. See supra pp. 840-4I. 
aspects of the histories can be shown by a comparison with the recent history of the Dalhousie Law School, ${ }^{56}$ long considered the Harvard of Canada for its practice of hiring teachers with graduate degrees from the apostolic successors to the chair of St. Christopher Langdell.

Although Canadian legal education has in large measure paralleled the American shift from undergraduate to graduate education $^{57}$ and although in the twenties Dalhousie largely pioneered the use of the case method in Canada, ${ }^{58}$ the latter event is not a special high point in the Dalhousie study; nor is the former shift a pervasive theme. This lack of emphasis is not surprising, for the identity of the professional law teacher in English-speaking Canada is not deeply bound up with case method teaching or with rising standards. Instead, the identity of this subspecies was critically shaped in a fight, extending into the fifties, between university law teachers of all stripes, most of whom could trace their pedigree back to Dalhousie, and the "benchers" of the Law Society of Upper Canada, who attempted to keep Ontario's Osgood Hall Law School the exclusive preserve of part-time, practitioner-teachers. ${ }^{59}$ The difference that this distinction makes in the form of the Dalhousie history is striking. Instead of having to think up something to say about the fifty or so years after standards have risen, as does the writer of an American law school history, the historian of Dalhousie has to fill out the sixty or so years between its establishment as the first university school in English-speaking Canada and the ultimate triumph of that form. In other words, whereas in the American version the climax comes too soon, in the Canadian version it is inordinately postponed. The narrative problem can be envisioned by sup-

${ }^{56} \mathrm{~J}$. Willis, A History OF DalHousie Law School (I979).

57 There is no history of Canadian legal education comparable to Stevens' history of American legal education. We base our assertion on J. Willis, supra note 57, at $39,68,72,86-87$, and a review of his sources. That is true for the balance of this paragraph as well.

${ }^{58}$ Id. at $82-84,105-07,135$. Professor Harry Arthurs has cautioned us that claims for the primacy of Dalhousie in this regard are in fact overdrawn by the author of Dalhousie's history. It is more likely, he suggests, that case method instruction sprang up all over Canada in the twenties. That this is true for at least one other law school is evident from Bucknall, Baldwin \& Larkin, Pedants, Practitioners and Prophets: Legal Education at Osgood Hall to 1957, 6 OsGood HALL L.J. I37, I95 (1968), a piece that screams out its theme - the rise of the professional law teacher.

s9 J. WILlis, supra note 56, at 7-8, 21 , II6, 139 , 151-52. Here again, Professor Arthurs cautions that, while as a matter of demonology the Dalhousie history is correct, in fact practitioners generally were the opponents of the spread of universitybased legal education in Ontario, and the leaders of that fight were faculty of Osgood Hall. Support for the second proposition can be found in Bucknall, Baldwin \& Larkin, supra note 58 , at 207-20. 
posing that Langdell had taught at Indiana University and that Harvard, Yale, and Columbia had only been converted after World War II. The Dalhousie historian struggles mightily with the problem and does manage to create two themes, both of which tie directly into the professional identity of the Canadian law teacher: the slow spread of Dalhousie's influence throughout Canada and the peculiar (to Americans) combination of the teacher and public servant, which distinguishes many of its teachers from its first dean down through those teaching during World War II.

Thus, looked at together, both the American and the Canadian volumes are about the same subject - the rise of the professional law teacher - but the details of that story, which seem to the American writers so necessary and important, are in fact somewhat accidental examples of several roads that might have been taken in differing social circumstances. And the emphasis placed on these accidental features only serves to underline what the story is really about. These books are only incidentally histories of law schools; primarily, they are testimonials. Like those some ninety years ago to Horsford's Acid Phosphate - "Decidedly beneficial in nervous exhaustion" 60 - these advertisements attest to the value and importance of the law teacher.

Once one identifies the reason why the themes of the case method and rising standards are central to these books, the balance of their content falls quickly into place with a certain dialectical flare. The law review-moot court world is taken to be the visible student culture of the law school because it does not undercut the notion of a scholarly vocation consistent with being a professor in a graduate school. The faculty too is largely invisible because the reality of indifferent, if often devoted, teaching and mediocre or nonexistent scholarship similarly belies the pretensions of professional self-image. Thus, the loss of momentum that is felt once the full-time, day program of instruction for graduate students is established in each of these books is the result of the author's perfectly understandable inability to confront reality when telling a story about the establishment of a professional identity wholly at odds with reality. Unable to validate the profession's selfimage in either students or teachers, the law school historian displaces his subject to one of progress, the orderly succession of deans, the acquisition of better quarters, and the faint possibility of excellence in the future.

${ }^{60} 2$ GreEN BAG miscellaneous advertisements (I8go) (quoting Dr. A.N. Krout). 
III.

Despite the flaws in all these works, first-rate, serious scholarship in the genre is possible. The best example is provided by the grand old man of the bunch, the Columbia history. Its main author was not Julius Goebel, who was too busy with other projects and thus contributed only the last half dozen pages of text, but Samuel F. Howard, Jr., one of Columbia's assistants in law hanging on for a year after completing his LL.B. ${ }^{61}$ An amateur with no graduate historiographic training, he resisted the project director's pressure to do something short and anecdotal, substantially completed the manuscript in a year at Columbia, and finished his task on nights and weekends while beginning practice. ${ }^{62}$ The result of his previously unsung efforts is a history that is eminently readable, sensitive to its cast of characters, often revelatory in its probing beneath the surface of events, and both encyclopedic in scope and teutonic in its painstaking documentation.

Similarly, Barnes' history of Hastings reads, as one would expect, like the work of a first-rate, professional historian. The prose moves well. Some of the characters in the play - Serranus Clinton Hastings, the founder, ${ }^{63}$ and Clara Shortridge Foltz, the first female student, ${ }^{64}$ and to a lesser extent John Norton Pomeroy, the first teacher ${ }^{65}$ - have real human dimensions. And some of the events that shaped the school are rendered clearly and convincingly, especially Serranus Hastings' fights with the trustees of his school ${ }^{66}$ and Clara

61

Professor Goebel was asked to write the Law School history; he was not interested in the matter, and suggested that the task be assigned to me. I was interviewed by the Columbia College professor who at the time was in charge of the overall project, and got the job. At the end of the semester, accordingly, my associateship was terminated and I became a member of the staff of the Foundation for Research in Legal History, to devote my full time to the projected history for a year.

. . Professor Goebel, who had other fish to fry, gave me a free hand to do what I pleased. He let me work in his office at Kent Hall (to which he came only to pick up his mail); he arranged for the Law School secretarial staff to type my manuscript as I wrote it; and he read over the typescript and pointed out some typographical errors I had overlooked; but that was the extent of his supervision. He had the 'final cut,' as they say in the moving picture business, but he did not try to exercise it, and he did not try to tell me what to write or how.

Letter from Samuel F. Howard, Jr., to John Henry Schlegel (Mar. 23, Ig80) (in possession of the authors).

${ }^{62} \mathrm{Id}$.

63 HASTINGS, supra note 3 , at II-42.

${ }^{64}$ Id. at $47-58$.

65 Id. at $89-$ I Io, II5-I 7 .

${ }^{66} \mathrm{Id}$. at $6 \mathrm{I}-87$. 
Foltz' fights with the trustees and the bar, both in and out of the courts. ${ }^{67}$ Also, the painstaking reconstruction of Pomeroy's "system" 68 is a real addition to our understanding of how law was taught before the "Harvardization" of law schools generally. Unfortunately, with the slow demise of that system under Pomeroy's successor, the force, interest, and clarity of the narrative decline markedly. This extended anticlimax contrasts with Howard's work, which drives hard all the way to the end, yet does an equally fine job on such characters as Theodore Dwight, and clearly and poignantly renders the events surrounding the demise of Dwight and his system.

Thus, the genre need not be dismissed entirely. But if we are to improve our knowledge of what goes on in law schools, then law school histories generally must start seeing people, both students and teachers, in their social settings, broadly construed to include the ideology of legal education. ${ }^{69} \mathrm{We}$ all know that law professors managed to acquire both an effective monopoly over legal education and a relatively insulated place in the modern university. ${ }^{70}$ We also know that just about every law school became a little Harvard, if only in its mind's eye. But our understanding of the life inside these institutions is still woefully incomplete. And a fuller grasp of the historical development of law schools would help us to comprehend and cope with the various problems in scholarship, teaching, and community that they face today.

Ever since James Bradley Thayer formulated a justification for the professional role of the American law teacher ${ }^{71}$ emphasis has been placed on the importance of scholarship for professional (and personal) advancement. Yet legal scholar-

${ }^{67}$ Id. at $47-58$.

68 Id. at roI-ro.

${ }^{69}$ See, e.g., Kennedy, First Year Law Teaching as Political Action, I LAw \& Soc. ProBs. 47 (1980); Note, Legal Theory and Legal Education, 79 YALE L.J. II53 (I970); Freeman, Race and Class: The Dilemma of Liberal Reform (Book Review), go YalE L.J. I880 (I98I); Klare, Book Review, 54 N.Y.U. L. REV. 876 (1979) (reviewing C. Knapp, Problems in Contract Law: Cases and Materials (r979)); R. Gordon, Lawyers and Legal Thought in the Age of Enterprise I-I2 (Oct. I98I) (unpublished manuscript on file in Harvard Law School Library). Intimately related to the work cited above are William Simon's two articles: Simon, The Ideology of Advocacy: Procedural Justice and Professional Ethics, 1978 WIS. L. REV. 29, and Simon, Homo Psychologicus: Notes on a Nero Legal Formalism, 32 STAN. L. REv. 487 (I980).

${ }^{70}$ The rise of the legal professoriat is, not surprisingly, contemporaneous with and related to the broader trend of professionalization in various disciplines within the university. See M. FURNER, AdvocaCy \& OBjectrvity 5, 316, 32 I (I975); T. HASKell, The EMErgence of Professional Social Science, 220-21 (1977); see also B. Bledstein, The Culture of Professionalism I89-9I, 282 (I976).

71 Thayer, The Teaching of English Law at Universities, 9 HARv. L. REv. I69 (1895). 
ship is in many ways a bad joke. The "shortness" of a typical law professor's vitae is one aspect of the problem. Another is the prevalence of pieces like The Rule in Dumpor's Case in Kansas: Toothless Tiger or Trap for the Unwary Draftsman?, and the twin evil, the ringing of the most minute changes on major constitutional cases such that the articles ought to be known not by author and title, but, like prints in a series, by number - Stone v. Powell No. 6I7. Yet there have been some extraordinary scholars in the profession - Wigmore, for example - as well as lesser but still significant lights like Walter Wheeler Cook, who remade conflict of laws in his own image; Karl Llewellyn, who did likewise with the sale of goods; and Lon Fuller, who substantially redirected thought in contract law. But the list is distressingly short. One possible explanation for the lack of original thinkers is that the reward structure within the law school is incompatible with serious scholarship. Teachers are chosen on the assurance that they will bear their share of the enormous class loads and participate in professional (read "safe") law reforms, bringing conservative bar support to the institution. Within such a reward structure, which often perpetuates itself through inbreeding in hiring, most scholarship is episodic, related to shifting teaching obligations or the vagaries of the bar's reform agenda rather than to any long-term academic commitment to advancing knowledge.

To say that scholarship is neglected for teaching, however, is not to say that law school teaching is adequate. The Socratic, teach-by-terror method and the constant diet of cases, whatever justification one might concoct for their use in firstyear submersion, seem to impede rather than facilitate learning in the second and third years. ${ }^{72}$ Yet professors continue to play the riddler, eking out as much as possible the limited information they have to impart.

Finally, inquiry into the problem of community within the law school might be very revealing. At times the level of fellowship among law professors seems to have been an important part of their lives. ${ }^{73}$ Now at almost every gathering of law professors, one finds in corners, and occasionally on the podium, grey countenances lamenting lost collegiality. ${ }^{74}$ This

72 See Harvard, supra note 5, at 283-84; Dunne, The Third Year Blahs: Professor Frankfurter After Fifty Years, 94 HARV. L. REV. 1237 (I981).

${ }^{73}$ See, e.g., Stanford, supra note 5 , at $4^{-16}$.

${ }^{74}$ At some schools the decline in community seems to have set in earlier:

The situation, except in the matter of appointments, seems to me to be that we are in no real sense a faculty, as I have understood a faculty in the other institutions with which I have been connected. We are strikingly without co- 
decline has been noted by the Berkeley historian, who first explained it as simply the result of the drain on faculty time due to university and law school administrative and law reform activities. ${ }^{75}$ But then she emphasized a more basic problem. Professors "are both tired and discouraged," feeling "a strong sense of demoralization." While there are mundane explanations for these symptoms - for example, budget cuts and inadequate salaries - several more significant ones can be found: "the unsatisfying relationships . . . between faculty and students," "the shift in age distribution of the faculty," the absence of "any distinctive dimensions to the school's academic program," and "a lack of consensus among faculty as to purpose." 76 These failures of collegiality and morale may merely be symptomatic of the failure of law schools generally.

\section{IV.}

Guesses about what future research might show are nearly all one comes away with after reading a pile of law school

operative intellectual interchange with regard to many matters affecting the longtime welfare of the school. I have known to the full the joy of sympathetic co-operation with fellow-faculty members to advance the interests of a department and of a School with which I was long associated. It was a personal satisfaction to participate in such co-operative planning and the results for the School and for each of us individually were results that we all saw to be good. I find the environment at the Harvard Law School strikingly different. As one of my colleagues here has put it, men here are hired to teach their courses and that is all that seems to be desired of them.

So it seems to me that we are no longer a school but a collection of separate individuals. How much this is due to the Dean, would be difficult to say. All we can be sure of is that a different Dean might make the situation considerably different. Young men come to the school to teach and know nothing of the institutional fellowship which made my life at Columbia so rich to me. For my own part I have accepted the situation as it is and have sought to make my personal adjustment to it by accepting my position as an individual hired to teach a course and not desired for any other reason. To younger men this makes for a sterility that menaces the opportunity of individual growth. It deprives them and some of the rest of us of institutional satisfactions that are inspiring. By contrast with what they know of other law schools, it makes their work here a dreary grind rather than a delightful adventure.

T. Powell, The Harvard Law School (c. I930) (unpublished manuscript in the Thomas Reed Powell Papers, Harvard Law School Library).

It is interesting to note the close parallel between Powell's lament and the observations of the Berkeley historian half a century later:

Whereas for most of its history, the faculty at Boalt Hall had been a small, tightly knit cohort of individuals who liked each other "indecently well," the camaraderie of earlier days has diminished, and relationships now tend to be a less meaningful and important part of daily life. The "spider web" phenomenon in which a network of relationships are bound together and in which activities in one area reverberate throughout the whole, no longer describes the climate; nor is the School seen as the friendly, relaxed, family-like place of earlier days.

Berkeley, supra note 5 , at $45^{2-53}$.

${ }^{75} \mathrm{Id}$. at $452-55$.

${ }^{76} \mathrm{Id}$. at $456-62$. 
histories - at least if one has any interest in the social dimensions of institutions. But one can hope for more. Lawyers make up a large part of America's elite, and we should know something about the training and shaping of that elite. Writing a law school history should be a subtle and demanding task. It calls for an analysis of at least three sets of variables: (I) the particular details of the social life, narrowly construed, of a law school; (2) the more general trends and movements in society at large over historical periods; and (3) the interaction of (I) and (2) with that most elusive of historical categories - ideology. These three inquiries need not be mutually exclusive, nor need pursuit of one methodologically undermine mastery of the others. There is no necessary tension between social context and ideology, parts and wholes, the particular and the general, though in most legal history those complex relationships are not even acknowledged. These law school histories do of course reflect an ideology without formally recognizing it. They are written as if what occurs in law school is both uninfluenced by and has no influence or impact on the outside world. But unconscious examples of the ideology of meritocratic, apolitical professional service do not tell us enough about a group that serves so many functions in American life. And we doubt that law professors would assert that the institutions they live in make no difference in the lives of their students or their society. For to paraphrase an old professor's line, an institution that makes no difference is no institution at all. 